\title{
Evaluation of the effectiveness of musical and melodramatic forms as a means of education
}

The verification of these methods and their effectiveness upon the mediation and dissemination of oral history in different cultural, social and historical environments

\section{Jana Konvalinková, Christopher Muffett}

\begin{abstract}
In 2019 the whole world commemorated 80 years since the beginning of one of the most tragic events of modern history, World War II. The project of the students and the teachers of the Technical University of Liberec (T.U.L) within the framework of the Student Grant Competition 2019, was born of these important events. The project perceived and conceived them from a pedagogical-didactic point of view. Expressive melodramatic approaches of conveying oral history became the starting point. The evacuation of children during World War II in England and Bohemia was an international project based on cooperation with the University of Suffolk from England. Prof. H. Osborne introduced to the students the historical background of England's evacuated children during World War II and facilitated meetings with living witnesses who were evacuated as children. An important parallel to these stories were the stories of the
\end{abstract}


Czech children known as the Winton children who were rescued on trains, and found salvation within English families.

The expressive, melodramatic retention and mediation of oral history from an artistic perspective, in the form of a compiled program, was a partial output of the project, addressing elementary and secondary school students and their teachers, university students and the general public in our country, England, Germany and Poland. In the second step, the project sought answers and wanted to verify the effectiveness of musical and melodramatic forms as a supporting means of education.

Key words: Education, music, music education, melodramatic procedures, oral history, pedagogy.

\title{
Hodnocení efektivity hudebních a melodramatických forem jako prostředku vzdělávání
}

Ověření těchto metod a jejich účinnosti pro zprostředkování a uchopení orální historie $v$ různých prostředích, kulturně, sociálně i historicky odlišných

\begin{abstract}
Abstrakt
V roce 2019 si celý svět připomínal 80 let od počátku jedné z nejtragičtějších událostí moderních dějin, 2. světové války. Projekt studentů a pedagogů Technické univerzity v Liberci v rámci Studentské grantové soutěže 2019 reagoval na tyto významné události a pojímal je z pedagogicko-didaktického hlediska. Expresivní melodramatické postupy ke zprostředkování orální historie byly východiskem. Evakuace dětí za 2. světové války v Anglii a Čechách byl mezinárodně pojatý projekt postavený na spolupráci s University of Suffolk z Anglie. Prof. H. Osborne představil studentům historické pozadí evakuovaných dětí Anglie za 2. světové války a umožnil, aby došlo k setkáním s žijícími pamětníky, kteř́ jako děti evakuaci zažili. Důležitou paralelou těchto příběhů byly přiběhy českých dětí tzv. Wintonových vlaků, které nacházely záchranu v prostředí anglických rodin.

Expresivně melodramatické uchopení a zprostředkování orální, ústně předávané historie uměleckým způsobem, formou komponovaného pořadu, byl dílčí výstup projektu, oslovil žáky základních, středních škol a jejich učitele, studenty univerzit i širokou veřejnost u nás, $v$ Anglii, $v$ Německu a Polsku. $V$ druhém kroku projekt hledal odpovědi a chtěl ověrit efektivitu hudebních a melodramatických forem jako podpůrného prostředku vzdělávání.
\end{abstract}


Klíčová slova: hudba, hudební výchova, melodramatické postupy, orální historie, pedagogika, vzdělávání.

DOI: $10.5507 /$ epd.2020.010

\section{Introduction}

2019 was the year when the whole world commemorated one of the most tragic events of the 20th century, the beginning of World War II. From pedagogical and sociological perspectives, it is very important to discuss topics related to this event. Due to the need to commemorate these historical events, teachers and students of the Technical University of Liberec decided to experiment with a combination of music, speech and melodramatic expression to introduce the theme of evacuated children of early World War II in Bohemia and England. They told the stories of Bohemian children from the so-called Winton trains and the stories of evacuated children from England. In August and September 1939, trains departed from London and Prague to evacuate a million and a half English children and 685 Bohemian children. All these children of Bohemia and England found their new home with unknown English families. The stories of Winton's children were more sorrowful; after the war they usually could not return to their families; they were deported to extermination camps during the war.

It was decided that oral history should be used as a pedagogical method, which in its lay form has a profound significance in pedagogical practice, where the aim is to educate not only with written academic words, but also with authentic oral stories. The collected personal testimonies of the so-called Winton children and British citizens, who as children were evacuated from strategic locations, provided a series of profound true stories of the darkest and brightest sides of humanity. The students carefully recorded and collected stories. Nine stories of oral history were interconnected with ten choral compositions. The power of the spoken word was supported by expressive music. However, the pedagogical goals were not only historical and musical, but also linguistic, as the stories had to be told in different languages. Four countries were selected: the Czech Republic, Germany, Poland and England. The task was to perform the show in these countries and to present the situation at the beginning of World War II in Europe. The challenge was to reach different audiences: children in schools in the UK and the Czech Republic, university students in all countries, and the general public in the Czech Republic, England, Germany and Poland. The performances were performed in Czech, English and German.

The project verified whether melodramatic practices in conjunction with oral history and choral compositions would provide a deeper impact on the understanding of 
historical events and human experience. This paper presents and describes the methodology and results of the whole project.

\section{Methodology}

\subsection{Oral history}

What is oral history? Oral history-learning from the oral communication of persons who were participants or witnesses of an event, process or time - is perceived in two ways. It is primarily a qualitative research method for researching societies controlled by regimes where there is no plurality of sources and where there is a prevalence of documents of state and party origin, which only recorded events that were considered significant by their originators. Outside the academic sphere in history, the oral history method is applied in journalism as well as in lay, communicative practice. It represents a significant stream for the transmission of "history" against the background of human experience, an experience that could not be transmitted because of the ideology of totalitarian assessment of facts, and where the sources of this information are inaccessible or destroyed (Vaněk 2011).

From the perspective of methodological and didactic procedures of future teachers, the lay form of oral history is also incorporated into the teaching process and is one of the motivating methods leading to active creative involvement of pupils in relation to the nearest surroundings, place of residence etc. (Vaněk 2011). The methodological portal of the Ministry of Education, Youth and Sports recommends the inclusion of the lay form of oral history in the classroom; it is supported because of its close links with those who have actually experienced historical events. It is recommended as an important motivational element (Herink 2014). The project enabled students to learn about the phenomenon of oral history and work with it, to process it and to prepare it for expressive melodramatic expression.

\subsection{Musical and dramatic methods}

Musical-dramatic methodical procedures are a frequently used phenomenon in pedagogy, but they are mostly related to the dramatic expression of a song or musical composition. We can find them often in literature linking songs with various activities (Kulhánková 2006, 2007, 2008, 2009), (Tichá 1999, 2007, 2009). They are a simplified concept of opera or ballet form. Other musical-dramatic techniques make use of alternating dramatic, spoken language with musical expression. This phenomenon is, besides the pedagogical level, very often used in music therapy, when students or clients respond to a given story or mood in a speech by instrumental play, most often by improvisation 
on elementary musical instruments (Šimanovský 1999, 2015), (Beníčková 2017). Musicdramatic techniques are also used by music-fiction. Here, too, clients can respond to narration, mood, colour, emotional experience or, most often, personally interpret the reproduced musical expression. The educational process is the methodical linking of the expressive form with the reflective dialogue. Most often, however, these are shorter musical areas, to which the personality of the individual subsequently responds in the form of reflective dialogue (Drlíčková 2014).

\subsection{Current use of melodramatic musical forms}

Melodramatic procedures are less used. Their application is based on the musical form of melodrama, which developed in the 18th and 19th centuries, (Fibich, Foerster, Suk, Martinů, Stravinsky and others), in which the spoken language accompanied by music is used, instead of singing. The form of melodrama exists in the form of concert or scene. These procedures always aim to increase the expressive effect of the text. Because of their difficulty in the area of instrumental play or other musical expression, they are often not used in the educational process. This project was a melodramatic rendition of oral history stories in conjunction with choral compositions. The project was based on the assumption that a melodramatic expression, a music-tinged text, will contribute to a stronger expressive experience, conveying a deeper understanding and understanding of historically important events (Powell 2018). In combination with the choral composition, the personality of the receiving individual can help to better understand the presented events on mental, emotional and physical levels. The project therefore wanted to grasp this process methodically and verify it.

\section{Survey and outputs}

Project Trains of Hope / I'll Take That One / Züge der Hoffung presented the questionnaire/survey a total of 21 times in 4 different countries. 10 times in the Czech Republic and 11 times abroad, in England, Poland and Germany. A total of 2,443 respondents were addressed. In the Czech Republic at 3 elementary schools for 230 pupils from 7th to 9th grades, 1 secondary school for 95 pupils, and 120 students from 2 universities, the Technical University of Liberec and the University of Hradec Králové. The questionnaire/survey was presented to the public twice, in the Shoah Memorial to commemorate the Holocaust in Liberec and in the Church of Sts. Antonín in Liberec, in cooperation with the Archdeacon of Liberec, under the auspices of the Liberec Region and the City of Liberec. A total of 780 students and teachers from the Technical University of Liberec, prominent personalities of the Liberec region and hon- 
orary guests - Winton's children, his Excellency Ambassador of the State of Israel and the audience.

Abroad, the project and its survey were presented 11 times.

In Germany at the University of Neisse in Gorlitz (35 students) and in the Marienthal monastery complex for students of the Evangelical High School of Herrnhut and the public (150).

In Poland at Karkonosze College in Jelenia Góra for 153 students.

In England 8 times, at 2 elementary schools (150 pupils), at the University of Suffolk (195 students, teachers and the public) and at 5 public presentations in the Suffolk regions (455 students).

The questionnaire/survey was completed by 2,443 respondents:

- 375 pupils from 7th to 9th grades of elementary schools and grammar schools in the Czech Republic

- 150 primary school pupils in England

- 120 High School Students in Germany

- 546 university students and teachers - Czech Republic, Poland, Germany, England

- 1385 public representatives

The survey asked:

1. Is the method of presenting personal stories with melodramatic expression a suitable means for a better understanding of the historical facts concerning the evacuation of the children of Bohemia and England at the beginning of World War II? Of the 2443 survey participants only 12 answered that they did not know, the other responded in the affirmative.

2. Is the method of expressive statement of oral history combined with music, vocal compositions and melodramatic practices seen as being appropriate and correct? Of the 2443 survey participants, only 8 responded that they did not know, the other answers were positive.

3. Which combined story of oral history and music was perceived by you as being "the strongest"?

Overall, no story with the highest preference was chosen. The stories preference showed balanced figures.

4. Through this performance did students of the universities in the Czech Republic, England, Poland and Germany have the opportunity to become acquainted with didactic-methodological procedures for the processing of oral history and specifically with expressive, musical-melodramatic procedures? Could these procedures be adopted within their curricula?

This part of the survey was only completed by university students and educators. 
546 interviewed students and university teachers in the Czech Republic, England, Poland and Germany responded yes to the first question and yes to the second if they would have materials enough to guide them.

5. Would they welcome school educators, parents and the public in general to develop courses or e-learning materials aimed at linking thematic units with expressive, musical-melodramatic approaches?

This part of the survey addressed school educators and the general public.

All of the 1,385 respondents representing the public and school teachers would welcome the opportunity to get acquainted with and to look at materials linking selected thematic units with an expressive concept.

\section{Work analysis and partial conclusions}

- Thanks to the questionnaire/survey, the project found that the proposed composed program was balanced and none of the oral history stories had a prevailing preference. This testified both to the power contained within each story and to the correct choice of expressive - melodramatic processing.

- The project firstly concluded that there were no differences in preferences and perceptions of the presented facts in countries of different cultural - and historical development. Secondly it demonstrated that this concert, this performance combing oral history and music, expressed well the integrity and courage of the real life players in this particular human drama. Thirdly it showed that fundamental humanity and human values were always superior to territorial division.

- The project opened the door to dialogues in the families of pupils and students and lead to the subsequent transfer of family experiences back to the school environment.

- The whole project achieved an unprecedented response, according to the evaluation of the questionnaire survey and also according to immediate reactions, discussions and comments. Methodological procedures combining the layman's form of oral history with expressive melodramatic musical have proved to be a right and appropriate means of expression of these historical stories.

- Adopted by all ages.

- The project together with the questionnaire survey reached a partial conclusion that the elaboration of methodological materials is an important step to enable similarly conceived projects to be implemented in schools, universities, in the environment of leisure activities or in families.

- In notes, discussions and reactions, the following conclusions were particularly perceived and appreciated: 
- The need and importance to report on the stories of the beginning of World War II and the theme of the evacuation of children in this period

- Respect for the actions of ordinary people who preserve the ideals of humanity must be given

- The programme was executed thoroughly

- Blending verbal expression with music creates an effective educational medium

- Stories and music for this period of history were appropriate and chosen well

\section{Conclusion}

This project defends the use of combined music and drama as an effective pedagogical tool in all levels of education. It also defends the effectiveness of interdisciplinary cooperation.

The original premises, which the students and teachers involved with the project tried to prove and defend, were proved and defended. It was assumed that the use of oral history associated with musical melodramatic would be one of the most effective methods of education. This was shown to be true as appreciated and stated in the statements by both addressed respondents and historians.

The fact that the project's audience demonstrated no overriding preference for any specific presented story and its musical composite showed that such a method of expression has the right balance of language, music and melodrama and is an effective tool of education. The project noted that it opens the door to dialogues in the families of pupils and students, and this leads to the subsequent transfer of family experiences back to the school environment. The project demonstrated that the profound significance of true human stories combined with music, contributes to deeper emotional interest, deepens the appreciation of this period, and also contributes to the "survival" of each presented life story.

Musical - didactic procedures were defended and these procedures will find their way to teachers and pupils of primary and secondary education as a result of this project. These procedures will become anchored into didactic methodology within the framework of the university education of future primary education teachers and music education specialists. The project's findings defended the importance of methodological procedures and their mediation through courses involving e - learning materials and scripts. The findings defended the readiness of the authors and the student team to create study materials. They also contributed to strengthening the reasoning behind music education being an essential part of the basic and general education of each individual. 


\section{References}

Beníčková, M. (2017). Muzikoterapie a edukace. Praha: Grada.

Drlíčková, S. (2014). Muzikofiletika. Arteterapie, 34(1), 33-41.

Kulhánková, E. (2007). Hudebně pohybová výchova: metodická príručka pro hudební výchovu ve škole. Praha: Portál.

Kulhánková, E. (2008). Písničky a říkadla s tancem. Praha: Portál.

Kulhánková, E. (2009). Řemesla ve hře, písni a tanci. Praha: Portál.

Kulhánková, E. (2006). Taneční hry s písničkami: od 4 let do 9 let. Praha: Portál.

Powell, J. (2018). Emoční síla krásných zvukú aneb proč máme rádi hudbu. Olomouc: Anag.

Šimanovský, Z., \& Tichá, A. (1999). Lidové písničky a hry s nimi. Praha: Portál.

Šimanovský, Z. (2015). Hry s hudbou a techniky muzikoterapie. Praha: Portál.

Tichá, A. (2009). Učíme děti zpívat: hlasová výchova pomocí her pro děti od 5 do 11 let. Praha: Portál.

Tichá, A. (2007). Zpíváme a hrajeme si s nejmenšími: od narození do 8 let. Praha: Portál.

\section{Contacts:}

MgA. Jana Konvalinková Ph.D.,

Technická univerzita v Liberci, FPHP, Katedra primárního vzdělávání,

Komenského 314/2, 46001 Liberec V - Kristiánov

Christopher Muffett M.A., PGCE

Technická univerzita v Liberci, FPHP, Katedra anglického jazyka

Komenského 314/2, 46001 Liberec V - Kristiánov

MgA. Jana Konvalinková Ph.D. teaches the didactics of music education, choral singing and other musical subjects in the department of Primary Education, Faculty of Education, Technical University of Liberec. She has long been involved in the integration of musical elements into the broader curriculum at the first level of primary schools. Examples of her publications include Český jazyk v rýmech aneb jak na to ř́kadlem, zpěvem a pohybem (2014), Člověk a jeho svět v pohádkách, řikadlech a písních (2018) and Environmentální výchova v pohádkách, ríkadlech a pisnich (2018). In addition, she is engaged in concert and choirmaster activities (The Bohemian choir FP TUL, choir Aurea Rosa U3V TUL), where she combines an artistic musical element with the spoken word in composed programs. These composed programs are thematically comprehensive and focus on the phenomenon of oral history. They are then processed in a multilingual form for international presentation. They are created and always implemented in cooperation with students of the Faculty of Education, so they also have a pedagogical purpose.

Examples of programmes which connect choral masterpieces with historical stories include Dark Times in Beautiful Places, tales from the 1948 to 1968 totalitarian period, Trains of Hope / Züge der Hoffnung ("Winton_Züge") stories of the evacuated children of Bohemia and England at the beginning World War II and When the Motherland Calls, sagas of local families and businesses over the last century. Project activities include scientific research and publication. 
Christopher Muffett M.A., PGCE is an English teacher at the Technical University of Liberec. $\mathrm{His}$ academic interests include performance and drama within the English curriculum. He has a strong interest in the preservation of social history through the oral tradition, in other words: storytelling.

He has been working in cooperation with Doctor Konvalinková, a music teacher at TUL, to create living historical and musical projects. The first project Dark times in beautiful places created an inspirational and unique performance. Audiences were treated to stories of Communism from the perspective of the families of the young student performers.

All three projects they have collaborated upon, have had the same format. Classical and contemporary choral music set the backdrop to live readings from the undergraduates. Their stories came from their families directly or were related to incidents which occurred within their grandparents 'lifetimes, the second project l'll take that one was focused on the European wartime evacuation of children.

The projects, including the current one, When the motherland calls, reflect current thinking in pedagogical practice. They are student centred and are created by the performers. Doctor Konvalinková and Mr Muffett believe they have found a unique formula, a magical combination of language, history and music. This formula resounds well with audiences of all ages and highlights the best of contemporary educational practice.

Christopher Muffett studied for his first degree at Edinburgh university and his second at the university of Wales. His chosen subject was English language and literature.

He has taught at illustrious universities throughout the world, such as the International University of Japan, the Warsaw School of Economics and the Technical University of Liberec. Before teaching in higher education, he was an elementary school teacher in England and Scotland, and a Fulbright exchange teacher in Millwaukee, USA. 